\title{
URGENSI IMPLEMENTASI STRATEGI DAKWAH di ERA KONTEMPORER
}

\author{
Oleh: Faridah ${ }^{1}$ \\ Jurusan Bimbingan Penyuluhan Islam \\ IAIM Sinjai
}

\begin{abstract}
ABSTRAK
Implementasi strategi dakwah di era kontemporer sangat penting dilakukan untuk mengantisipasi semakin kompleksnya problematika dakwah yang dihadapi. Ragam problematika dakwah kontemporer memerlukan beberapa upaya pembenahan dalam aktivitas dakwah agar tujuan dakwah dapat tercapai secara maksimal. Upaya yang dibutuhkan dalam pelaksanaan dakwah di antaranya adalah perencanaan dan pengaturan dalam aktivitas dakwah untuk mencapai tujuan dakwah yang telah dirumuskan. Dalam aktivitas dakwah, perencanaan yang matang akan menjadi peta jalan pada kegiatan dakwah sehingga pelaksanaan agenda dakwah akan lebih fokus dan terkontrol, efektif dan efisien, serta komprehensif-integratif.
\end{abstract}

Keywords : Urgensi Strategi Dakwah Kontemporer.

\section{PENDAHULUAN}

\section{A. Latar Belakang Masalah}

Perkembangan dan perubahan zaman yang semakin pesat menimbulkan ragam dampak baik dampak positif maupun negatif pada masyarakat. Kemudahan dan kelancaran dalam hal komunikasi dan beberapa aspek kehidupan lain termasuk beberapa dampak positif dari perubahan zaman. Namun, selain perubahan dalam hal positif, perubahan dalam hal negatif hampir berbanding lurus. Pergesaran nilai-nilai moral, budaya dan keagamaan merupakan beberapa hal yang mengalami kemerosotan tajam.

Pergeseran nilai-nilai moral dan keagamaan masyarakat merupakan suatu hal yang memerlukan berbagai upaya dalam rangka membendung dan meminimalisasi krisis degradasi moral masyarakat akibat perubahan dan perkembangan zaman yang sangat pesat. Desain dakwah dalam menjawab tantangan zaman di era kontemporer pun diharapkan dapat efektif dan efisien karenanya penting untuk menerapkan strategi dakwah yang sesuai.

\footnotetext{
${ }^{1}$ Dosen Tetap IAI Muhammadiyah Sinjai 
Penerapan strategi dakwah yang sesuai dengan perkembangan zaman di mana media sosial sudah menjadi raja sangatlah penting dan patut menjadi pertimbangan. Hal ini dapat menjadi suatu langkah utama melihat dan memperhatikan semakin kompleksnya problematika dakwah kontemporer. Dalam kerumitan problematika dakwah, strategi dakwah diharapkan mampu menjawab tantangan dakwah di tengah maraknya aktivitas dakwah kontemporer yang masih menyisakan tanda tanya akan efektivitas dan efisiensi pelaksanaannya.

Maraknya aktivitas dakwah yang semakin ramai menghiasi media massa seperti media cetak dan media elektronik terutama media audio visual belum mengindikasikan tercapainya tujuan dakwah. Kesulitan dalam menemukan arah dan tujuan dakwah masih mewarnai analisis aktivitas dakwah yang terlaksana. Dakwah yang masih bersifat sendirisendiri dan belum memiliki keseragaman tujuan mengakibatkan tujuan-tujuan dakwah belum dapat dicapai dengan maksimal. Hal ini memunculkan problematika dakwah seperti aktivitas dakwah yang asal-asalan, spontan, parsial, tidak inovatif dan bersifat tambal sulam. ${ }^{2}$

Ragam problematika dakwah di tengah hingar-bingar pelaksanaan dakwah kontemporer menggambarkan perlunya pembenahan dengan pengenalan medan dakwah dan penyusunan perencanaan dan persiapan dakwah sehingga dakwah yang dilakukan dapat terarah. Adanya perencanaan dan persiapan dalam pelaksanaan dakwah diharapkan mampu menjadi problem solving pada aktivitas dakwah sehingga tujuan dakwah dapat tercapai atau dakwah bisa lebih efektif dan efisien.

\section{B. Rumusan Masalah}

Berdasarkan latar belakang masalah yang telah dikemukakan, maka fokus pada penelitian ini adalah:

1. Bagaimana urgensi strategi dakwah di era kontemporer?

2. Bagaimana problematika dakwah di era kontemporer?

3. Bagaimana bentuk strategi dakwah di era kontemporer?

\footnotetext{
${ }^{2}$ Ibnu Qomar el-Banthory,dkk. Peta Dakwah di Indonesia, Pamulang: Formadina press, 2010, h. 56.
} 


\section{PEMBAHASAN}

\section{Analisis Strategi Dakwah Kontemporer}

\section{A. Strategi Dakwah dan Urgensinya}

Strategi merupakan salah satu upaya yang dilakukan untuk mencapai tujuan pelaksanaan suatu kegiatan. Istilah strategi berasal dari bahasa Yunani yang berarti kepemimpinan atas pasukan atau seni memimpin pasukan. Strategi berasal dari kata strategos yang merupakan perkembangan kata stratos (tentara) dan agein (pemimpin), istilah strategi dipergunakan dalam konteks militer sejak kejayaan Yunani-Romawi sampai masa awal industrialisasi. Istilah strategi akhirnya meluas ke berbagai aspek aktivitas masyarakat termasuk dalam bidang dakwah dan komunikasi. Perluasan dan penerapan strategi dalam berbagai bidang termasuk dalam bidang dakwah ini sangat penting karena adanya tujuantujuan tertentu yang dikehendaki dalam aktivitas dakwah yakni terjadinya perubahan dalam masyarakat khususnya masyarakat yang dibina. ${ }^{3}$

Pentingnya penerapan strategi dalam bidang dakwah dan komunikasi diakibatkan oleh penerimaan dan tingkat pemahaman masyarakat tentang suatu pesan yang berbeda bahkan ada yang sangat menonjol. Tingkat penerimaan dan pemahaman masyarakat ini disebabkan oleh berbagai hal seperti latar belakang sosial budaya, pendidikan, dan wilayah domisili. Berbagai hal ini juga merupakan suatu acuan untuk penerapan strategi dakwah. Di samping itu, pengaruh modernisasi telah mengambil peran yang sangat besar dalam merubah tata kehidupan masyarakat. Adanya perkembangan dan perubahan zaman akibat modenisasi tersebut memerlukan pemikiran dan langkah strategis untuk mengantisipasi pengaruh buruk perkembangan dan perubahan zaman yang sangat cepat dan pesat.

Wahyu Ilaihi dan Harjani Hefni Polah menganalisis kondisi dakwah kontemporer menyatakan bahwa pada saat ini dunia sebenarnya menitipkan harapan besar terhadap dakwah Islam. Setelah runtuhnya komunisme, masyarakat kontemporer hampir binasa oleh moralitas yang rendah dan terjadi fraksi besar dalam peta kekuatan dunia. Adanya minat yang besar terhadap agama Islam oleh seluruh kalangan di dunia merupakan suatu hal yang

${ }^{3}$ Anwar Arifin, Dakwah Kontemporer: Sebuah Studi Komunikasi (Cet I: Yogyakarta: Graha Ilmu, 2011) h. 227. 
penting untuk mendapat perhatian. Kondisi ini merupakan peluang besar bagi kaum muslim yang mau bekerja sabar dan serius dalam berdakwah. ${ }^{4}$

Beragam problematika dakwah yang ditemukan serta adanya minat yang tinggi terhadap agama Islam merupakan suatu kondisi yang memerlukan suatu upaya penanganan serius dan terencana. Upaya yang dilakukan dalam hal ini bertujuan untuk mengantisipasi dan mengentaskan problematika dakwah serta menjawab kebutuhan masyarakat terhadap agama Islam. Dakwah yang selama ini dianggap sebagai denyut nadi Islam memerlukan upaya dan langkah yang tepat dalam pelaksanaannya. Upaya dan langkah tersebut tercakup dalam perencanaan dakwah yang merupakan hakikat dari strategi dakwah.

Muh.Ali Aziz mendefinisikan strategi dakwah sebagai perencanaan yang berisi rangkaian kegiatan yang didesain untuk mencapai tujuan dakwah tertentu. Hal utama yang harus diperhatikan dalam hal ini menurut Wina Sanjaya seperti di kutip oleh Muh.Ali Aziz adalah:

1. Strategi merupakan rencana tindakan (rangkaian kegiatan dakwah) termasuk penggunaan metode dan pemanfaatan berbagai sumber daya atau kekuatan. Strategi dalam hal ini dimaksudkan sebagai proses penyusunan rencana kerja belum sampai pada tindakan.

2. Strategi disusun untuk mencapai tujuan tertentu. Hal ini berarti arah dari semua keputusan penyusunan strategi adalah pencapaian tujuan, sehingga sebelum menentukan strategi perlu merumuskan tujuan yang jelas serta dapat diukur keberhasilannya. ${ }^{5}$

Menganalisis definisi strategi berdasarkan pendapat Muh. Ali Aziz dan Wina Sanjaya mengindikasikan bahwa langkah penetapan strategi dakwah mengutamakan perencanaan dakwah yang didesain berdasarkan tujuan dakwah yang akan dicapai.

Perencanaan dakwah yang diharapkan menjadi landasan tindakan dalam melakukan aktivitas dakwah merupakan salah satu upaya yang dilakukan dalam menentukan tujuan dan target suatu aktivitas dakwah melalui pengumpulan data dan menganalisisnya kemudian merumuskan metode dan tata cara untuk merealisasikannya seoptimal mungkin. Hal ini

\footnotetext{
${ }^{4}$ Wahyu Ilaihi dan Harjani Hefni Polah, Pengantar Sejarah Dakwah,(cet:2: Jakarta: Rahmat Semesta, 2012), h. 238.

${ }^{5}$ Moh. Ali Aziz, Ilmu Dakwah Edisi Revisi,(Cet.II; Jakarta: Kencana, 2009), h. 349-350.
} 
menggambarkan bahwa perencanaan dakwah haruslah memiliki tiga unsur utama yakni pengumpulan data, analisis data, dan penyusunan rencana yang konkrit. ${ }^{6}$

Unsur-unsur dalam perencanaan dakwah yang mencakup tiga komponen, yakni pengumpulan dan analisis data lapangan kemudian penyusunan rencana konkrit diharapkan mampu menjadikan desain aktivitas dakwah dapat lebih terarah sehingga hasil yang diharapkan bisa lebih optimal. Untuk mencapai hasil yang optimal, perencanaan dakwah semestinya didesain dengan mempertimbangkan dan menganalisis berbagai hal terutama analisis terhadap komponen-komponen dakwah.

Komponen-komponen dakwah yang penting untuk menjadi bahan analisis dan mendapat porsi utama perhatian dalam perencanaan dakwah meliputi tujuan, dai, mad'u, materi, metode, media dan efek dakwah. Secara konkrit analisis dan pertimbangan terhadap komponen dakwah dapat diuraikan secara ringkas berikut:

1. Penetapan tujuan dakwah, baik jangka pendek, menengah dan jangka panjang. Langkah ini dilakukan agar aktivitas pencapaiannya bisa lebih terarah.

2. Pemilihan dai yang sesuai yakni dai yang memahami, mampu berbaur dan menyesuaikan diri dengan mad'u yang dihadapi.

3. Analisis kondisi mad'u yakni pemahaman tentang kondisi objektif mad'u baik tingkat pendidikan, segi okupasional, kondisi sosial budaya dan beberapa hal yang terkait dengan tingkat penerimaan dan pemahaman mad'u.

4. Pemberian materi berdasarkan kebutuhan, hal ini dapat lebih mengefektifkan dan mengefisienkan pelaksanaan dakwah karena penerimaan terhadap sesuatu yang dibutuhkan lebih cepat dan mudah.

5. Penerapan metode yang tepat. Materi dakwah yang disampaikan dengan metode yang tepat dapat menimbulkan ketertarikan dalam aktivitas dakwah.

6. Penggunaan media yang sesuai. Penggunaan media dalam aktivitas dakwah di era kontemporer penting untuk menjadi perhatian karena peran dan penggunaan media utamanya media komunikasi yang sudah sangat mewabah dan menjamur. Pemanfaatan media dalam hal ini dapat menjadikan dakwah semakin mudah tersebar luaskan.

${ }^{6}$ Ibnu Qomar el-Banthory,dkk. Peta Dakwah di Indonesia, Pamulang: Formadina press, 2010, h. 57. 
7. Analisis efektivitas dakwah. Aktivitas dakwah selayaknya dilakukan dengan tidak menafikan pada analisis efektivitas dakwah, karena dengan adanya analisis terhadap efektivitas dakwah, maka dakwah bisa lebih terarah.

Cakupan perencanaan dakwah yang terdiri atas komponen-komponen dakwah dengan analisis dan pengenalan medan dakwah untuk pertimbangan desain berdasarkan analisis fungsi serta peran setiap komponen dakwah penting untuk diperhatikan. Di samping itu, hal lain yang perlu ditetapkan adalah perencanaan dakwah dari segi waktu dapat dibagi dalam tiga bagian yaitu:

1. Jangka panjang yakni program yang dapat diklasifikasikan dalam target 10-20 tahunan. Program jangka panjang merupakan pandangan jangka jauh yang akan menentukan kualitas kehidupan umat Islam ke depan. Dinamika kehidupan yang terus berkembang mengahruskan umat Islam memiliki visi pembangunan jangka panjang agar tidak tersisihkan oleh zaman. Bagaimana model pendidikan Islam 20 tahun ke depan dan bagaimana pola pemberdayaan ekonomi umat 15 tahun ke depan?

2. Jangka menengah yakni capaian target dalam 3-5 tahun. Jangka ini bisa berubah sesuai dengan rancangan tahun yang ditetapkan. Secara konsep, target jangka menengah bertujuan sebagai penunjang menuju capaian target jangka panjang. Program ini dapat merujuk pada rencana strategis (renstra) kementerian agama program jangka menengah yang meliputi:

a. Peningkatan kualitas pemahaman dan pengamalan agama masyarakat,

b. Pengembangan kehidupan social yang harmonis, rukun, dan damai di kalangan umat beragama,

c. Peningkatan kualitas pelayanan bagi umat beragama,

d. Peningkatan kualitas penyelenggaraan ibadah haji, optimalisasi potensi dan pendayagunaan dana sosial keagamaan,

e. Peningkatan kualitas dan kapasitas lembaga sosial keagamaan,

f. Peningkatan kebijakan dan tata kelola kehidupan beragama yang baik dan

g. Peningkatan akses dan kualitas pendidikan Raudhatul athfal, madrasah, perguruan tinggi agama pendidikan agama dan pendidikan keagamaan. 
3. Jangka pendek yakni program yang lebih difokuskan pada penyelesaian masalah keumatan dalam jangka pendek, dalam artian program ini lebih fokus pada persoalan yang muncul temporal di masyarakat. ${ }^{7}$

Penentuan target yang dicapai dalam perencanaan dakwah dengan rentan waktu yang telah ditentukan merupakan pedoman aktivitas yang mengharuskan upaya yang serius untuk mewujudkannya. Pentingnya penerapan strategi dakwah di era kontemporer menjadi acuan dan pertimbangan mengingat fungsi dan tujuan dari strategi dakwah dengan penetapan hakekatnya pada perencanaan dakwah yang berfungsi sebagai:

1. Menjadi peta jalan (road map) kegiatan dakwah sehingga pelaksanaan agenda dakwah akan lebih fokus dan terkontrol, efektif, efisien dan komprehensif-integratif.

2. Dapat memberikan kepercayaan diri pada para aktivis dakwah karena mereka merasa menjalankan suatu pekerjaan yang telah teruji secara konseptual. ${ }^{8}$

Menganalisis berbagai hal terkait terhadap peran dan fungsi strategi dakwah sebagai upaya penanganan dan antisipasi dalam aktivitas dakwah demi tercapainya efektivitas dakwah mengindikasikan pentingnya perencanaan dan pengaturan aktivitas dakwah. Perencanaan dan pengaturan tersebut hendaknya meliputi segala aspek atau komponenkomponen dakwah. Penetapan desain perencanaan dakwah yang merupakan hakikat atau inti dari strategi dakwah apabila dilakukan dengan sungguh-sungguh dan terkoordinasi dengan baik, maka desain tersebut mampu menjadi kompas dakwah.

\section{Analisis Dakwah Kontemporer dan Problematikanya}

\section{A. Problematika Dakwah Kontemporer}

Era kontemporer merupakan era globalisasi dan perkembangan teknologi komunikasi yang semakin canggih dan modern. Aktivitas dakwah di era kontemporer mengalami tantangan yang berbeda dari yang lainnya. Perencanaan dan penataan dakwah dalam hal ini juga harus berbeda berdasarkan konteks pelaksanaan dakwah. Proses modernisasi yang sangat pesat memerlukan desain strategi yang dapat mengikuti perkembangan zaman. Upaya ini diperlukan mengamati adanya pergeseran besar-besaran dalam tata kehidupan masyarakat

\footnotetext{
65.

${ }^{7}$ Ibnu Qomar el-Banthory,dkk. Peta Dakwah di Indonesia, Pamulang: Formadina press, 2010, h..60-

${ }^{8}$ Ibnu Qomar el-Bnthory,dkk. Peta Dakwah di Indonesia, Pamulang: Formadina press, 2010, h. 56.
} 
baik pergeseran nilai budaya, nilai sosial, agama maupun pergeseran dalam berbagai aspek kehidupan lainnya.

Media sosial yang sudah menelisik hingga di bilik-bilik masyarakat merupakan salah satu peluang dan tantangan dakwah yang membutuhkan desain dakwah yang sesuai agar aktivitas dakwah yang dilakukan dapat benar-benar menyentuh ruang berpikir dan merasa masyarakat yang akhirnya diharapkan mengantarkan masyarakat tersebut pada pengimplementasian pesan dakwah yang diterima.

Perkembangan zaman yang pesat sesungguhnya berbanding lurus dengan semerbak dan maraknya aktivitas dakwah. Hal ini ditandai dengan menjamurnya aktivitas-aktivitas dakwah baik yang face to face maupuan yang melalui media komunikasi. Gerakan dakwah kontemporer yang dapat diamati dan dianalisis terdiri atas:

1. Dakwah yang bersifat personal, digerakkan oleh tokoh ulama dan dai karismatik yang memiliki pengaruh besar di tengah-tengah masyarakatnya.

2. Dakwah jamaah yang berdakwah dalam bentuk organisasi yang terstruktur rapi. Dakwah jamaah ini pun beragam ada yang dibentuk oleh masyarakat yang yang peduli terhadap sesama dan ada yang dibentuk resmi oleh pemerintah. ${ }^{9}$

Merebaknya aktivitas dakwah ditengah laju arus modernisasi dengan beragam dampak negative yang ditimbulkan diharapkan mampu menjadi problem solving terhadap problematika aktivitas dakwah. Anwar Arifin menyatakan beberapa hal tentang problematika dan tantangan dakwah kontemporer yang menjadi indikasi pentingnya strategi dakwah untuk mengantisipasi dan penanganannya, yaitu:

1. Banyaknya informasi atau pesan media massa yang tidak sejalan dengan dakwah seperti manipulasi informasi dalam periklanan dan tayangan kekerasan serta pornografi (gambar cabul).

2. Banyak konten dalam jejaring sosial atau internet (international networking) di dunia maya yang langsung menantang dakwah terutama konten pornografi yang didukung oleh liberalisme, pragmatisme, materialisme dan sekuarisme serta kebebasan informasi yang sedang melanda dunia melalui globalisasi.

\footnotetext{
${ }^{9}$ Wahyu Ilaihi dan Harjani Hefni Polah, Pengantar Sejarah Dakwah,(Cet:2: Jakarta: Rahmat Semesta, 2012), h. 236.
} 
3. Manusia yang memiliki potensi dan kecenderungan membandel dari fitrah dan kehanifannya dengan melakukan sikap dan perilaku yang negatif yaitu zalim dan kafir, bakhil, membantah, membandel serta berbuat dosa.

4. Penggunaan media dan pemilihan metode yang tidak tepat sehingga khalayak lebih banyak menggunakan daya tangkalnya (kepala batu) daripada daya serapnya.

5. Media massa yang tidak berpihak kepada dakwah dan Islam, dapat merekayasa opini sehingga citra dakwah dan Islam menjadi buruk di mata dan benak publik. ${ }^{10}$

Senada dengan Anwar Arifin, Wahyu Ilaihi dan Harjani Hefni Polah menyatakan bahwa, tantangan dan problematika dakwah kontemporer adalah adanya serangan luar yang dahsyat baik yang dihadapkan kepada diri dai atau organisasi dakwah maupun kepada masyarakatnya. Serangan tersebut terdiri atas beragam bentuk seperti serangan militer, ekonomi, pemikiran dan social. Serangan ini mampu memperlebar radius permasalahan di lapangan dakwah. ${ }^{11}$

Berbagai problematika dan tantangan dakwah kontemporer berdasarkan analisis umum dan pendapat serta analisis para ahli merupakan berbagai hal sangat urgen untuk diperhatikan dan ditangani dengan tepat. Di samping problematika-problematika yang telah dipaparkan, terdapat juga beberapa faktor penghambat terlaksananya dakwah, yaitu:

1. Pelaku amar makruf nahi mungkar yakni dai yang kurang memahami mana yang makruf dan mana yang mungkar.

2. Kualitas umat yakni keterbatasan umat Islam dalam bidang tertentu yang menyebabkan keliru dalam memahami ajaran agama serta adanya umat Islam yang berpegang teguh pada bunyi teks al-Quran atau sunnah tanpa memperhatikan konteksnya.

3. Kehadiran teknologi informasi, adanya kepincangan yang menyolok dalam arus globalisasi dan informasi. ${ }^{12}$

Analisis terhadap problematika, tantangan dan faktor penghambat terlaksananya dakwah memerlukan kerjasama dari berbagai pihak yang berkompetensi serta peduli terhadap aktivitas dakwah untuk merumuskan dan beberapa langkah strategis sebagai bentuk

${ }^{10}$ Anwar Arifin, Dakwah Kontemporer; Sebuah Studi Komunikasi (Cet.1: Yogyakarta: Graha Ilmu, 2011), h. 225-229 2012), h. 237.

${ }^{11}$ Wahyu Ilaihi dan Harjani Hefni Polah, Pengantar Sejarah Dakwah,(Cet:2: Jakarta: Rahmat Semesta,

${ }^{12}$ Sampo Seha, Paradigma Dakwah: Menata Ulang Penerapan Dakwah di Indonesia, h. 157-161. 
upaya penanganan dan antisipasi terhadap problematika dakwah kontemporer guna pencapaian efektivitas dakwah.

\section{B. Analisis Implementasi Strategi Dakwah di Era Kontemporer}

Era kontemporer merupakan era modernisasi yang sangat pesat. Ragam dinamika modenitas mewarnai kehidupan masyarakat kontemporer. Berbagai fenomena kehidupan yang ditemui dan dijalani memerlukan pemikiran yang cermat dan cerdas untuk memaksimalkan peluang dakwah yang terbuka dan menjawab tantangan dakwah yang menghadang.

Pergeseran nilai-nilai kehidupan yang sangat cepat dan pesat banyak menimbulkan problematika dalam kehidupan umat. Kesiapan masyarakat untuk menjalani kehidupan yang sangat keras dan seolah tidak memberikan ruang untuk berpikir tentang perencanaan kehidupan yang akan dijalani boleh dikata sangat minim sehingga gejala patologi sosial ${ }^{13}$ banyak ditemukan.

Pergeseran nilai dalam segenap aspek kehidupan menimbulkan pergolakan yang sebagian besar berimplikasi pada problematika dan tantangan dakwah kontemporer. Ragam tantangan dakwah berdasarkan berbagai persepektif dan analisis strategi dakwah yang diharapkan menjadi solusi penanganan dakwah di era kontemporer dapat dilihat sebagai berikut:

1. Perspektif perilaku, salah satu hal yang menjadi tujuan dakwah adalah terjadinya perubahan perilaku (behavior change) pada masyarakat yang menjadi objeknya menuju situasi yang lebih baik. Antisipasi terhadap tantangan dakwah perspektif perilaku berupa strategi dakwah dengan pendekatan teori komunikasi yang tepat.

2. Tantangan dakwah perspektif transmisi (transmissional perpektive), pada tantangan ini dakwah diartikan sebagai proses penyampaian atau transmisi ajaran Islam dari dai sebagai sumber kepada mad'u agar dapat bersikap dan bertingkah laku sesuai ajaran agama yang diterimanya.

3. Tantangan dakwah perspektif interaksi. Tantangan ini menjelaskan bahwa masyarakat yang menjadi objek dakwah pasti berinteraksi dengan pihak-pihak lain atau masyarakat

\footnotetext{
${ }^{13}$ Semua tingkah laku yang bertentangan dengan norma kebaikan, stabilitas local, pla kesederhanaan, moral, hak milik, solidaritas kekeluargaan, hidup rukun bertetangga, disiplin, kebaikan dan hukum formal. Kartini Kartono, Patologi Sosial jilid I (Cet,13, Jakarta: raja grafindo persada, 2013), h. 1.
} 
sekitarnya termasuk masyarakat dunia yang dapat saja membawa pesan-pesan yang tidak Islami.

4. Tantangan dakwah perpektif transaksional. Tantangan ini timbul akibat pembauran antara peradaban barat dan timur yang ditemukan dalam berbagai aspek kehidupan. ${ }^{14}$

Penerapan strategi dakwah dengan ragam perspektif seperti yang telah dipaparkan diharapkan mampu menjawab tantangan-tantangan dakwah yang ditemukan. Upaya penerapan strategi dakwah tersebut diawali dengan penetapan tujuan dakwah, dengan mengetahui tujuan dakwah diharapkan penentuan upaya yang akan dilakukan untuk mencapai tujuan dakwah sesuai dan tepat sasaran. Adapun penetapan tujuan dakwah harus disesuaikan dengan kondisi objektif mad'u yang akan dihadapi karena kebutuhan mad'u akan dakwah beragam.

Mad'u dalam aktivitas dakwah terbagi atas berbagai jenis, hal ini memerlukan strategi dakwah yang berbeda sesuai dengan kondisi objektif mad'u yang dihadapi. Al-Bayanuni dalam hal ini membagi strategi dakwah atas tiga jenis seperti dikutip Moh.Ali Aziz sebagai berikut:

1. Strategi sentimentil (al-manhaj al'athifi) yaitu dakwah yang berfokus pada aspek hati dan menggerakkan perasaan dan batin mad'u. strategi ini mengembangkan metode pemberian nasihat, memanggil dengan kelembutan dan memberikan pelayanan yang memuaskan. Metode ini dapat diterapkan pada mad'u yang terpinggirkan (marginal), wanita, anakanak, orang awam, mualaf dan sebagainya.

2. Strategi rasional (al-manhaj al'aqli), merupakan strategi dakwah yang berfokus pada aspek akal pikiran, bagaimana mendorong mad'u untuk berpikir, merenung dan mengambil pelajaran.

3. Strategi indriawi (al-manhaj al-hissi) yaitu strategi eksperimen atau strategi ilmiah berupa kumpulan metode dakwah yang berorientasi pada pancaindera dan berpegang teguh pada hasil penelitian dan percobaan. ${ }^{15}$

Ragam strategi dakwah seperti yang telah dipaparkan diharapkan mampu menjadi menjadi acuan untuk menerapkan strategi dakwah yang sesuai dengan kondisi objektifitas

\footnotetext{
${ }^{14}$ Malik Idris, Strategi Dakwah Kontemporer (Cet. I; Makassar: Sarwah Press, 2007 h. 94-115.

${ }^{15}$ Moh. Ali Aziz, Ilmu Dakwah Edisi Revisi, h. 351-353.
} 
mad'u. Penerapan strategi dakwah yang sesuai merupakan upaya penanganan dan pengentasan problem solving terhadap problematikan dakwah kontemporer. 


\section{DAFTAR PUSTAKA}

Arifuddin, Metode Dan Strategi Dakwah Bi Al-Hikmah (Cet.1, Makassar: Alauddin University Press, 2012.

---------, Metode Dakwah Dalam Masyarakat Plural; Sebuah Penelitian Kualitatif , Ciputat: Sejahtera Kita, 2012.

Amin, Muliaty, Teori-Teori Ilmu Dakwah (Cet.1, Makassar: Alauddin Press, 2011

Arifin, Anwar, Dakwah Kontemporer: Sebuah Studi Kontemporer, Yogyakarta: Graha Ilmu, 2011.

Acep Arifuddin, Pengembangan Metode Dakwah: Respon Dai Terhadap Dinamika Kehidupan Beragama Di Kaki Ciremai (Cet.1, Jakarta:Rajagrafindo Persada, 2011.

Ali Azis, Moh, Ilmu Dakwah, Edisi Revisi, Jakarta:Kencana, 2009.

El-Banthory Ibnu Qomar,dkk. Peta Dakwah di Indonesia, Pamulang: Formadina press, 2010.

Faizah dan Muchsin Effendi, Lalu, Psikologi Dakwah, Jakarta: Kencana, 2009

Ilaihi, Wahyu dan Polah, Harjani Hefni, Pengantar Sejarah Dakwah, Jakarta: Kencana, 2007.

Ilyas Ismail, A, dan Hotman, Prio, Filsafat Dakwah: Rekayasa membangun Agama dan Peradaban Islam, Jakarta: Kencana, 2011.

Idris, Malik, Strategi Dakwah Kontemporer, Makassar: Sarwah Press 2007

Jumantoro, Totok, Psikologi Dakwah: Dengan Aspek-Aspek Kejiwaan Yang Qur'ani, Penerbit Amzah, 2001.

Munir, M, dkk, Metode Dakwah Edisi Revisi, Jakarta; Kencana, 2009.

Muhyiddin, Asep dan Ahmad Safei, Agus, Metode Pengembangan Dakwah (Cet.1, Bandung: Pustaka Setia, 2002.

Nasional, Departemen Pendidikan, Kamus Besar Bahasa Indonesia Edisi Ketiga, Jakarta: Balai Pustaka, 2005.

RI, Departemen Agama, Al-Qur'an Dan Terjemahnya, Jakarta: Darus Sunnah, 2012.

Muhammad Said, Nurhidayat, Dakwah \& Efek Globalisasi Informasi, Makassar: Alauddin University Press, 2011.

Saputra, Wahidin, Pengantar Ilmu Dakwah (Cet. 1, Jakarta; Raja Grafindo Persada, 2011. 